\title{
APLIKASI PENDAFTARAN DAN PENERIMAAN SISWA BARU DI SMK NEGERI 1 RUPAT BERBASIS WEB DAN SMS GATEWAY
}

\author{
Siti Suherni ${ }^{1}$, Nur Rubiati ${ }^{2}$, Hayatullah Khumaini ${ }^{3}$ \\ ${ }^{1,2,3}$ Sekolah Tinggi Manajemen Informatika dan Komputer (STMIK) Dumai \\ Jl.Utama Karya bukit Batrem II Dumai-Riau kode pos 28811 \\ e-mail : sitisuherni42@gmail.com
}

\begin{abstract}
ABSTRAK
Pendaftaran dan penerimaan calon siswa baru di SMK Negeri 1 Rupat masih menggunakan media kertas untuk pendaftaran, karena belum ada aplikasi yang dibuat khusus untuk pendaftaran secara online. Pada umumnya petugasmengharuskan dapat memberikan pelayanan yang cepat kepada caloncalon siswa yang mendaftar. Dengan itu perlu adanya sistem yang dapat membantu kinerja tata usaha dalam melayani calon-calon siswa baru yang mendaftar dan memberikan pelayanan tambahan dengan bantuan aplikasi sms gateway dalam penyampaikan informasi kepada orang tua /wali siswa yang mendaftar. Maka dari itu dibuatlah sebuah aplikasi pendaftaran calon siswa baru secara online dengan berbasis sms gateway agar lebih efektif dan efisien dalam penyampain informasi penerimaan siswa baru. Dengan adanya Aplikasi ini, dapat mempermudah bagi pihak sekolah dalam pengolahan data Pendaftaran dan Penerimaan Calon Siswa Baru.
\end{abstract}

Kata kunci : Pendaftaran, Penerimaan, SMS Gateway.

\section{PENDAHULUAN}

Sekolah Menengah Kejuruan (SMK) Negeri 1 Rupat dibuka pada tahun 2008, yang pada awalnya hanya terdiri dari 2 program yaitu Agribisnis Tanaman Perkebunan dan Agribisnis Ternak Ruminansia. Pada tahun 2010 dibuka program keahlian baru yaitu Teknik Komputer dan Jaringan. Sekolah Menengah Kejuruan (SMK) Negeri 1 Rupat terletak di jl.Taman Siswa No.02 Kelurahan Pergam Kecamatan Rupat Kabupaten Bengkalis Provinsi Riau.

Sekolah menengah Kejuruan (SMK) Negeri 1 Rupat merupakan salah satu lembaga pendidikan formal yang berkembang di Rupat. Dilihat dari aktivitas yang ada pada bagian petugas dan tata usaha dalam pengelolaan data pendaftaran dan penerimaan calon siswa baru masih menggunakan media kertas untuk pendaftaran. Ketika siswa menyerahkan formulir pendaftaran kepada tata usaha, formulir pendaftaran calon siswa baru masih disimpan dalam bentuk arsip, sehingga rentan terhadap kehilangan dan kerusakan berkas karena terlalu banyak siswa yang mendaftar. Proses input data pendafaran membutuhkan waktu yang lama dan berdampak pada lamanya informasi yang dibutuhkan.

Apabila tata usaha dan kepala sekolah membutuhkan data pendaftaran dan data penerimaan calon siswa baru harus mencari data satu-persatu dari seluruh data yang ada sampai data yang diinginkan ditemukan. Kendala lainnya juga yang menjadi masalah utama adalah kurangnya informasi dari pihak sekolah kepada orang tua atau wali siswa mengenai informasi dimana calon siswa mendaftar sekolah.

Sehingga dengan adanya aplikasi pendaftaran dan penerimaan calon siswa berbasis web dan sms gateway ini dapat mempermudah tata usaha dan pihak sekolah dalam pengolahan data pendaftaran dan penerimaan siswa baru, juga mempermudah bagi orang tua atau wali siswa dalam mengetahui dimana calon siswa mendaftar sekolah.

\section{a. Pengertian Sistem.}

kata "sistem" berasal dari kata Latin "systema" dan kata Yunani "sustema". Sistem adalah sekelompok unsur yang erat hubungannya satu dengan yang lain, yang berfungsi bersama-sama untuk mencapai tujuan tertentu. Jadi, secara umum sistem adalah suatu kesatuan yang terdiri dari komponen atau elemen-elemen yang dihubungkan untuk 


\section{INFORM T I K A}

Jurnal Informatika, Manajemen dan Komputer, Vol. 9 No. 2, Desember 2017

eISSN : 2580-3042

pISSN : 1979-0694

memudahkan aliran informasi. (Kaharu, Sakina, Informasi, \& Data, 2016)

sistem terdiri dari berbagai unsur yang saling melengkapi dalam mencapai tujuan dan sasaran. Unsur-unsur yang terdapat dalam sistem itulah yang disebut dengan subsistem. Subsistemsubsistem tersebut harus saling berhubungan dan berinteraksi melalui komunikasi yang relevan sehingga sistem dapat bekerja secara efektif dan efisien.(Iswandy, 2015)

\section{b. Pengertian Informasi}

Informasi adalah data yang telah diolah sehingga lebih berarti dan berguna bagi penerima. Jadi, sumber dari informasi adalah data. Informasi juga sekumpulan fakta (data) yang telah diorganisasikan dengan cara tertentu sehingga memiliki arti bagi penerima. Informasi adalah hasil pengolahan data dalam bentuk yang lebih berguna dan lebih berarti, yang menggambarkan kejadian (event) yang nyata (fact), dan dapat digunakan untuk pengambilan keputusan. (Kaharu et al., 2016)

Informasi merupakan Data yang telah diolah menjadi sebuah bentuk yang berarti bagi penerimanya dan bermanfaat bagi pengambilan keputusan saat ini atau saat mendatang. (Iswandy, 2015)

\section{c. Pengertian Sistem Informasi}

Sistem informasi adalah sistem yang dapat mengumpulkan, memperoses, menyimpan, menganalisis, dan menyebarkan informasi untuk tujuan tertentu. Sistem informasi terdiri atas input berupa data dan instruksi, dan output berupa laporan dan kalkulasi.

Sistem informasi adalah sistem yang mempertemukan kebutuhan pengolahan transaksi harian dan mendukung fungsi manajerial organisasi dengan strategi organisasi untuk menyediakan laporan-laporan kepada pihak luar tertentu.(Kaharu et al., 2016)

Sistem informasi adalah suatu sistem yang tujuannya menghasilkan informasi. Sebagai suatu sistem, untuk dapat memahami sistem informasi, akan lebih baik jika konsep dari sistem itu dipahami terlebih dahulu. Demikian juga sebagai sistem penghasil informasi, maka konsep informasi perlu dipahami terlebih dahulu.(Saputra, 2015)

\section{d. Pengertian Penerimaan Siswa Baru}

Penerimaan merupakan penyambutan, proses, perbuatan atau sikap terhadap seseorang. Siswa merupakan pelajar pada akademi atau perguruan tinggi. Baru merupakan suatu hal

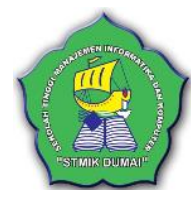

belum ada sebelumnya".(Witanto \& Solihin, 2016)

\section{e. SMS Gateway}

Short Message Service (SMS) adalah kemampuan untuk mengirim dan menerima pesan dalam bentuk teks dari dan kepada ponsel. Teks tersebut bisa terdiri dari huruf, angka atau kombinasi alphanumeric. SMS Gateway adalah komunikasi menggunakan SMS yang mengandung informasi berupa nomor telepon seluler pengirim, penerima, waktu dan pesan. Informasi tersebut dapat diolah dan bisa melakukan aktivasi transaksi tergantung kodekode yang sudah disepakati. Untuk dapat mengelola semua transaksi yang masuk dibutuhkan sebuah sistem yang mampu menerima kode SMS dengan jumlah tertentu, mengolah informasi yang terkandung dalam pesan SMS dan melakukan transaksi yang dibutuhkan. Aplikasi SMS Gateway adalah sebuah perangkat lunak yang menggunakan bantuan komputer dan memanfaatkan teknologi seluler yang diintegrasikan guna mendistribusikan pesan-pesan yang dipadukan lewat sistem informasi melalui media SMS yang ditangani oleh jaringan seluler. SMS Gateway biasanya support untuk pesan yang berupa teks, unicode character, dan juga smart messaging (ringtone, picture message, logo operator dan lain-lain).(Afrina, Ibrahim, Sistem, Fasilkom, \& Sriwijaya, 2015).

SMS Gateway adalah teknologi mengirim, menerima dan bahkan mengolah sms melalui komputer dan sistem komputerisasi (software). Seperti kita ketahui, pada zaman sekarang, hampir semua individu telah memiliki telepon selular (handphone), bahkan ada individu yang memiliki lebih dari 1 handphone. SMS merupakan salah satu fitur pada handphone yang pasti digunakan oleh pengguna (user), baik untuk mengirim, maupun untuk menerima sms. Dari segi kecepatan sms, semakin banyak terminal (handphone / modem) yang terhubung ke komputer (dan disetting ke software sms), maka semakin cepat proses pengiriman smsnya.

\section{f. CSS (Cascading Style Sheet)}

CSS (Cascading Style Sheet) adalah stylesheet language yang digunakan untuk mendeskripsikan penyajian dari dokumen yang dibuat dalam mark up language. CSS merupakan sebuah dokumen yang berguna untuk melakukan pengaturan pada komponen halaman web, inti dari dokumen ini adalah memformat halaman web standar menjadi 


\section{IN F O RM A I K}

Jurnal Informatika, Manajemen dan Komputer, Vol. 9 No. 2, Desember 2017

eISSN : 2580-3042

pISSN : 1979-0694

bentuk web yang memiliki kualitas yang lebih indah dan menarik. (Binarso, Sarwoko, \& Bahtiar, 2012)

CSS adalah suatu cara untuk membuat format atau layout halaman web menjadi lebih menarik dan mudah dikelola [2]. CSS muncul karena sulitnya mengatur layout tampilan dokumen yang dibuat dengan HTML murni meskipun telah menggunakan berbagai kombinasi format.(Dana Pranata, Hamdani, 2015)

\section{g. Notepad++}

Notepad++ adalah sebuah aplikasi text editor yang bersifat gratis. Notepad menitikberatkan kegunaan aplikasi untuk editing text dalam waktu yang cepat dan praktis. Notepad++ mendukung banyak format bahasa pemrograman seperti PHP, HTML, JavaScript dan CSS. Aplikasi ini dapat diunduh secara bebas di alamat "notepad-plus-plus.org". (Palevi \& Krisnawati, 2013)

\section{h. PHP}

PHP merupakan bahasa script yang ditampatkan dalam server dan diproses diserver. Hasilnyalah yang dikirimkan ke client, tempat pemakai menggunkan browser. (K, Irfan, Nurpianti, Teknik, \& Fakultas, 2013)

PHP singkatan dari PHP: Hypertext Preprocessor yang digunakan sebagai bahasa script server-side dalam pengembangan web yang disisipkan dalam dokumen HTML Penggunaan PHP memungkinkan web dapat dinamis sehingga maintenance situs web tersebut menjadi lebih mudah dan efisien. PHP merupakan software Open-source yang disebarkan dan dilisensikan secara gratis serta dapat di download secara bebas dari situs resminya. (Bangun et al., 2014)

\section{i. MySQL}

MySQL adalah sebuah perangkat lunak system manajemen basis data SQL (database management system) atau DBMS yang multithread, multi-user,dengan sekitar 6 juta instalasi di seluruh dunia.(K et al., 2013)

MySQL (My Structure Query Language) adalah salah satu DataBase Management System (DBMS). MySQL berfungsi untuk mengelola database menggunakan bahasa SQL. MySQL bersifat open source sehingga kita bisa menggunakannya secara gratis. Pemrograman PHP juga sangat mendukung/support dengan database MySQL.(Bangun et al., 2014)

\section{METODE PENELITIAN}

Untuk membantu dalam penyusunan metode penelitian ini, maka perlu adanya susunan kerangka kerja yang jelas tahapantahapannya. Kerangka kerja ini merupakan langkah-langkah yang akan dilakukan dalam penyelesaian masalah yang ada di SMK Negeri 1 Rupat, berikut adalah kerangka kerja:

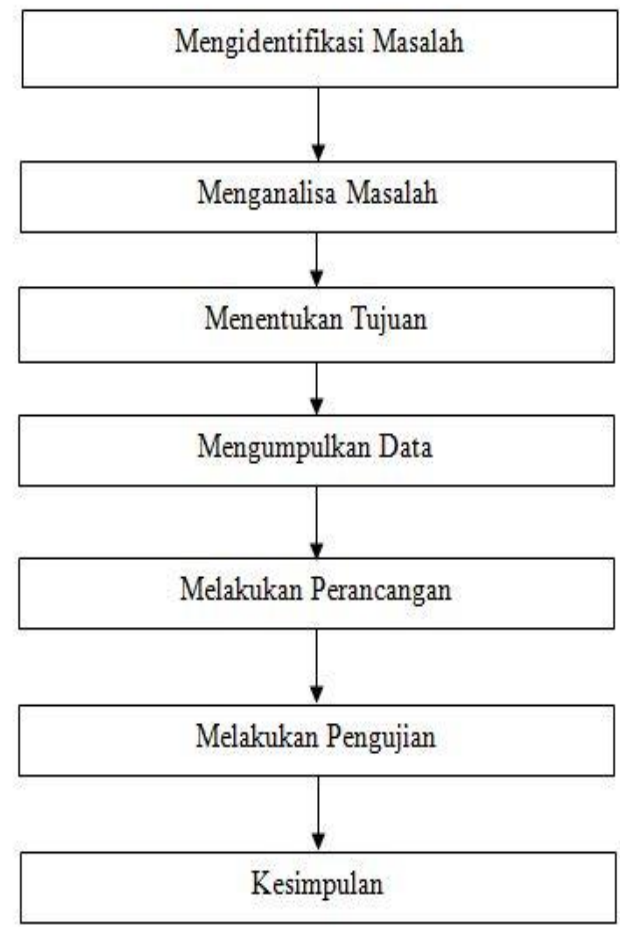

Gambar 1. Kerangka Kerja

Berdasarkan gambar diatas, dapat dijabarkan urutan-urutan langkah kerja sebagai berikut:

1. Mengidentifikasi Masalah

Permasalahan utama dalam penelitian ini adalah sistem yang ada saat ini masih menggunakan media kertas untuk pendaftaran.

2. Menganalisa Masalah

Penganalisaan terhadap masalah yang telah diidentifikasikan perlu dilakukan, apakah data mengenai pendaftaran dan penerimaan siswa baru di SMK Negeri 1 Rupat dapat dianalisa dan ditambahkan dengan aplikasi pendaftaran dan penerimaan siswa baru dengan bantuan web dan SMS Gateway. Dengan tujuan untuk mempermudah menyampaikan informasi kepada orang tua atau wali siswa perihal pendaftaran dan penerimaan siswa baru tersebut. 
IN F ORM T IK A

Jurnal Informatika, Manajemen dan Komputer, Vol. 9 No. 2, Desember 2017

eISSN : 2580-3042

pISSN : 1979-0694

3. Menentukan Tujuan

Tujuan utama dalam penelitian ini adalah untuk menyediakan informasi kepada orang tua atau wali siswa mengenai pendaftaran dan penerimaan siswa baru berbasis SMS Gateway.

4. Mengumpulkan Data

Pengumpulan data mengenai data pendaftaran dan penerimaan siswa baru diperoleh dengan cara melakukan pengamatan langsung ke SMK Negeri 1 Rupat.

5. Melakukan Perancangan

Adapun penjelasan lebih rinci mengenai perancangan aplikasi pendaftaran dan penerimaan calon siswa baru pada SMK Negeri 1 Rupat digambarkan menggunakan Contex Diagram, DFD, Permodelan Output, Permodelan Input, Permodelan Data, Hipo.

6. Melakukan Pengujian

Melakukan pengujian merupakan proses terakhir sebelum mendapatkan pengetahuan baru dari data yang ada. Pada tahap ini, hasil penerapan SMS Gateway menggunkan software Gammu.132 akan dilakukan pengujian kembali, dengan tujuan untuk mendapatkan hasil yang maksimal dari data yang ada.

\section{Kesimpulan}

Setelah dilakukan pengujian, langkah berikutnya adalah penentuan/pengambilan keputusan berdasarkan hasil yang telah dilakukan sebelumnya, sehingga akan muncul hasil program yang prioritas atau yang tudak prioritas.

\section{HASIL DAN PEMBAHASAN}

a. Aliran Sistem Informasi Yang Sedang Berjalan (ASI Lama)

Aliran Sistem Informasi yang sedang berjalan (ASI Lama) pada sistem Pendaftaran dan Penerimaan Calon Siswa Baru di SMK Negeri 1 Rupat dilihat pada gambar 2 sebagai berikut:

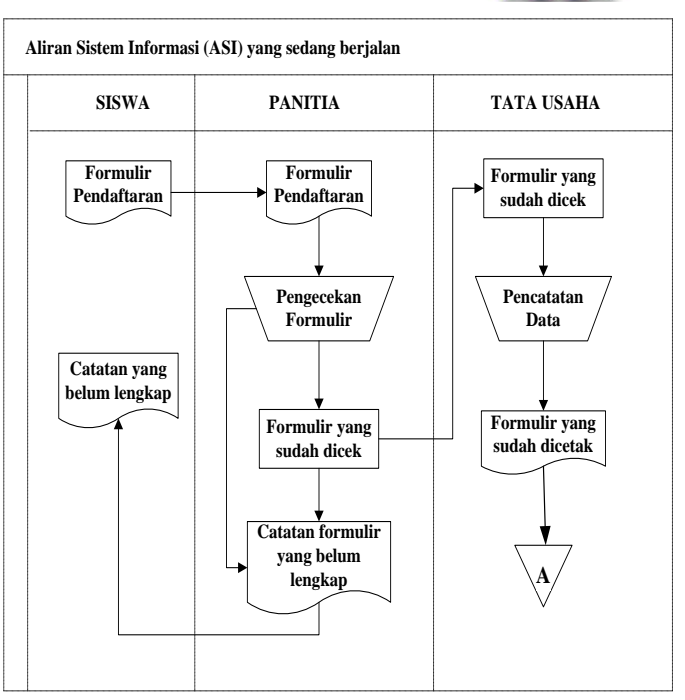

Gambar 2. ASI Lama

Berikut adalah keterangan dari gambar 2 aliran sistem informasi yang sedang berjalan (ASI Lama) pada Aplikasi Pendaftaran dan Penerimaan Siswa Baru di SMK Negeri 1 Rupat Berbasis Web dan Sms Gateway yaitu:

1. Calon siswa mendaftarkan diri kesekolah SMK Negeri 1 Rupat.

2. Kemudian panitia memberikan formulir pendaftaran.

3. Siswa mengisi formulir pendaftaran tersebut.

4. Setelah diisi siswa memberikan kembali formulir pendaftaran kepada paniti.

5. Panitia mengecek formulir pendaftaran yang lengkap dan tidak lengkap.

6. Formulir yang sudah lengkap diserahkan kepada tata usaha.

7. Tata usaha langsung menginput data calon siswa tersebut.

8. Setelah diinput, kemudian diarsifkan.

9. Jika yang belum lengkap panitia memberikan catatan kepada siswa.

b. Aliran Sistem Informasi Yang Sedang Berjalan (ASI Baru)

Berikut gambar serta keterangan dari gambar 3 aliran sistem informasi yang baru pada sitem pendaftaran dan penerimaan calon siswa baru di SMK Negeri 1 Rupat. 
I N F ORM A I I A

Jurnal Informatika, Manajemen dan Komputer, Vol. 9 No. 2, Desember 2017

eISSN : 2580-3042

pISSN : 1979-0694

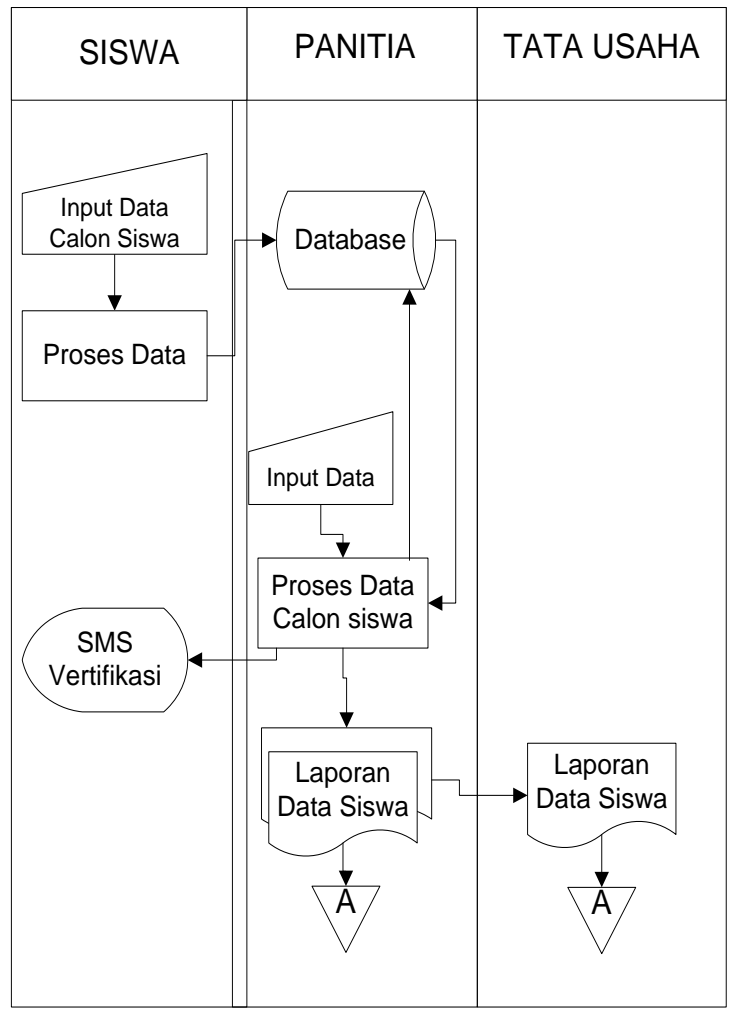

Gambar 3. ASI Baru

Berikut adalah keterangan dari gambar 3 aliran sistem informasi yang sedang berjalan (ASI Lama) pada Aplikasi Pendaftaran dan Penerimaan Siswa Baru di SMK Negeri 1 Rupat Berbasis Web dan Sms Gateway yaitu:

1. Siswa membuka website SMK Negeri 1 Rupat.

2. Siswa mendaftarkan diri kesekolah SMK Negeri 1 Rupat melalui website.

3. Siswa mengisi form pendaftaran yang telah disediakan. Kemudian masuk sms verifikasi data pendaftaran kepada calon siswa dan orang tua/wali siswa. kemudian siswa login terlebih dahulu dengan username dan password yang telah dikirim melalui sms.

4. Setelah siswa login, siswa mengisi form persyaratan. Kemudian Petugas mengecek data persyaratan lengkap dan yang belum lengkap, lalu masuk sms verifikasi data persyaratan tersebut.

5. Kemudian siswa menunggu hasil kelulusan dan pengumuman daftar ulang melalui sms berikutnya.

6. Setelah selesai, petugas membuat laporan data pendaftran Keseluruhan, laporan data pendaftaran pertahun ajaran, laporan data persyaratan, dan laporan data kelulusan masing-masing sebanyak 2 rangkap. Kemudian petugas memberikan kepada kepala sekolah untuk mengecak dan minta 
IN F O RM A I I A

Jurnal Informatika, Manajemen dan Komputer, Vol. 9 No. 2, Desember 2017

eISSN : 2580-3042

pISSN : 1979-0694

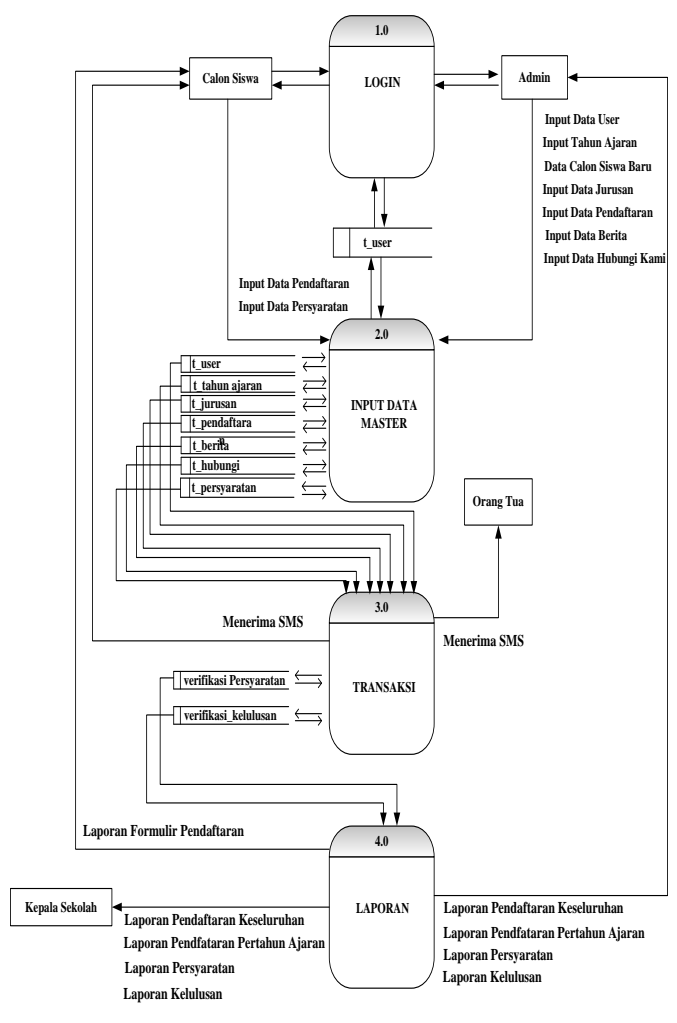

Gambar 5. DFD Level 1

\section{e. Tampilan Program}

1. Menu Utama Umum

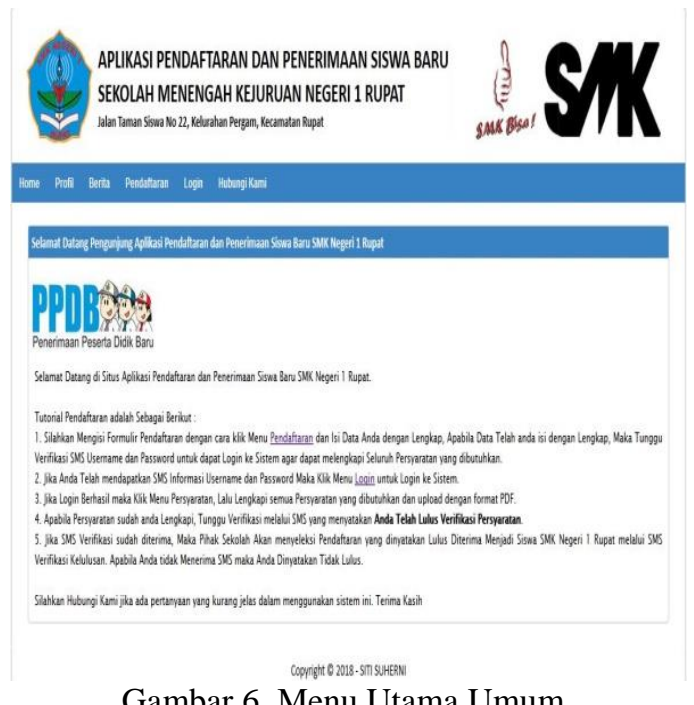

Gambar 6. Menu Utama Umum

menu utama umum merupakan menu yang dapat mengakses oleh semua pengguna. Dalam menu utama umum terdapat beberapa halaman menu yang memiliki fungsi dan kegunaan masing-masing yaitu Halaman Home, Halaman Profil, Halaman Berita, Halaman Pendaftaran,

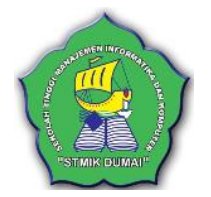

Halaman Login, dan Halaman Hubungi kami. Didalam Halaman home terdapat tutorial pendaftaran dan penerimaan siswa baru di SMK Negeri 1 Rupat.

\section{Halaman Login}

Halaman login merupakan langkap awal untuk masuk ke munu utama masing-masing penggguna. Halaman login terbagi menjadi dua yaitu :

1. Halaman Login Siswa

Didalam halaman login siswa, siswa memasukkan username dan password yang didapat melalui sms pertama kehalaman login siswa. Jika username dan password benar maka akan tampil ke halaman menu utama, jika username dan password salah maka halaman login akan kembali kehalaman menu home.

2. Halaman login admin

Halaman login admin bertugas untuk melakukan pengecekan dan memverifikasi datadata calon siswa.
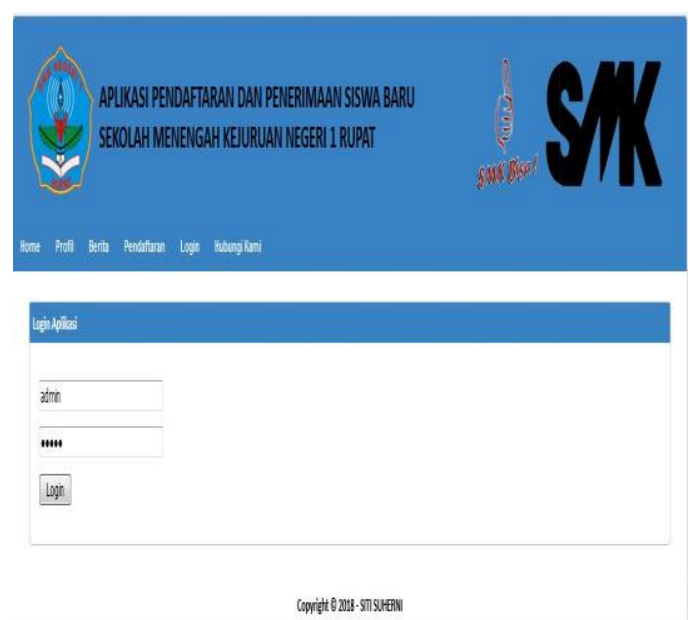

Gambar 7. Halaman Login Admin/Siswa

Didalam login admin dan login siswa terdapat menu-menu yang memiliki fungsi masing-masing pengguna.

\section{Menu Utama Umum Admin}

Didalam menu utama admin terpadat menu-menu yang memiliki fungsi masingmasing yaitu, menu home kembali kemenu utama, menu master memiliki beberapa sub menu yaitu menu user, menu tahun ajaran, menu calon siswa baru, menu jurusan, menu pendaftaran, menu berita, menu hubungi kami. Dimenu transaksi memiliki beberapa sub menu yaitu menu veririfikasi persyaratan, dan menu verifikasi kelulusan. Dimenu laporan memiliki beberapa sub menu yaitu menu laporan 
INFORM T IKA

Jurnal Informatika, Manajemen dan Komputer, Vol. 9 No. 2, Desember 2017

eISSN : 2580-3042

pISSN : 1979-0694

pendaftaran keseluruhan, menu laporan pendaftaran pertahun ajaran, menu laporan persyaratan, dan menu laporan kelulusan. Sedangkan dimenu pengaturan memiliki beberapa sub menu yaitu menu ubah password, menu visi misi, menu tanda tangan.

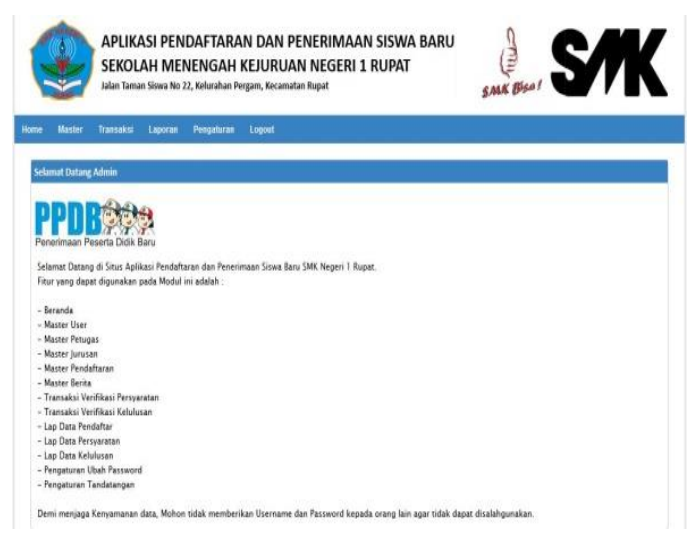

Gambar 8. Halaman Menu Utama Admin

4. Halaman Menu Utama Siswa

Didalam halaman menu utama siswa terdapat menu-menu yang memiliki fungsi masing-masing yaitu, menu beranda, menu pforil, menu berita, menu persyaratan, menu laporan, menu pengaturan, dan men hubungi kami.

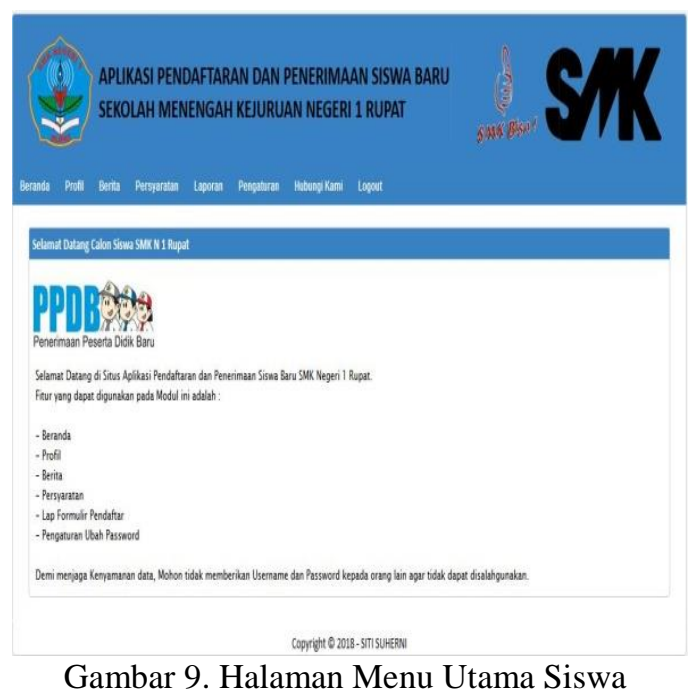

\section{Data Pendaftaran}

Didalam halaman pendaftaran terdapat input pendaftaran untuk calon siswa baru. Siswa mengisi data pribadi siswa satu-persatu, kemudian simpan dengan mengklik tombol daftar. Setelah data siswa terdaftar maka otomatis masuk sms ke nomor handphone siswa dan orang tua/wali siswa untuk mendapatkan

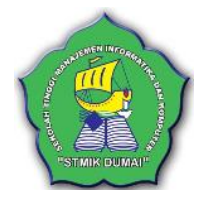

usrname dan password login agar dapat mengisi data selanjutjnya.

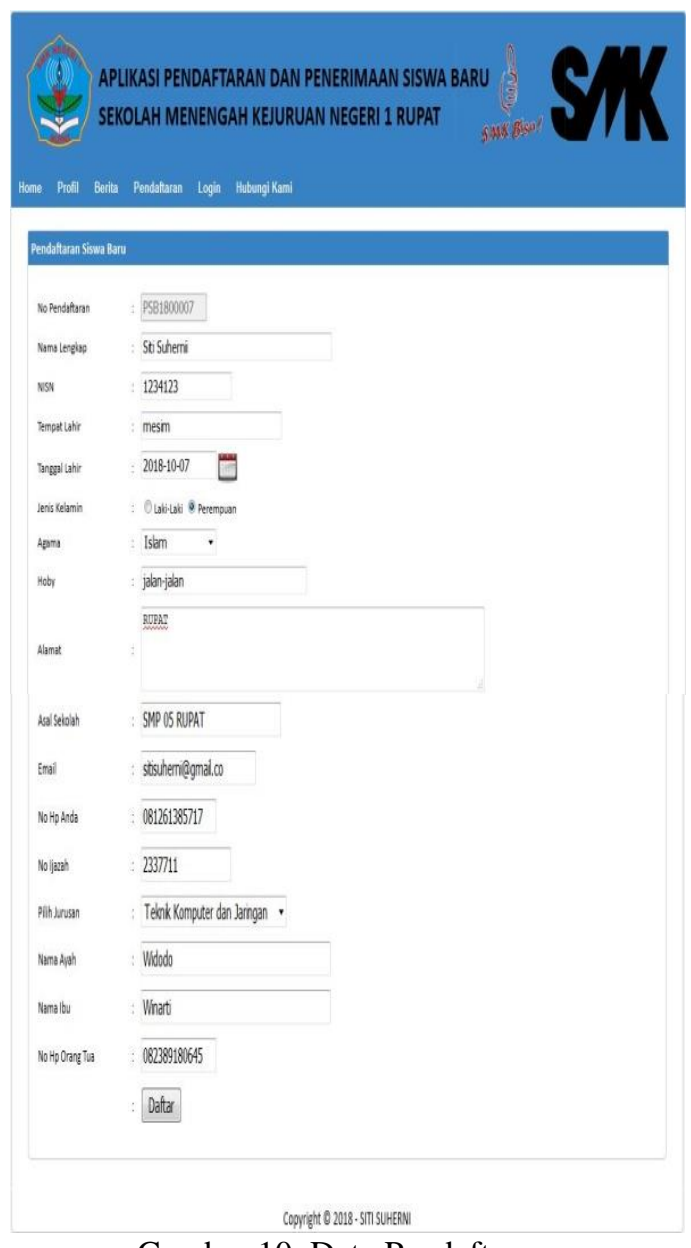

Gambar 10. Data Pendaftaran

6. Data Persyaratan

Setelah siswa login, siswa menginput data persyaratan yang sudah ada di menu utama siswa. Siswa menginput data persyaratan satupersatu berbentuk PDF/JPG. Jika siswa salah menginput data persyaratan siswa bisa menghapus persyaratan yang sudah di apload sebelumnya dengan menggunakan tombol

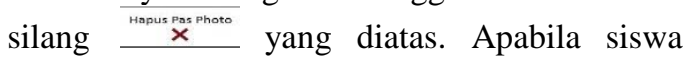
belum lengkap mengapload persyaratan, form persyaratan bisa disimpan dan bisa kembali mengapload persyaratan selengkap lengkapnya dengan login kembali. Setelah siswa melengkapi persyaratan atau tidak melengkapi persyaratan maka akan masuk sms handphone orang tua/wali siswa tentang persyaratan tersebut. 
I N F ORM A I I A

Jurnal Informatika, Manajemen dan Komputer, Vol. 9 No. 2, Desember 2017

eISSN : 2580-3042

pISSN : 1979-0694

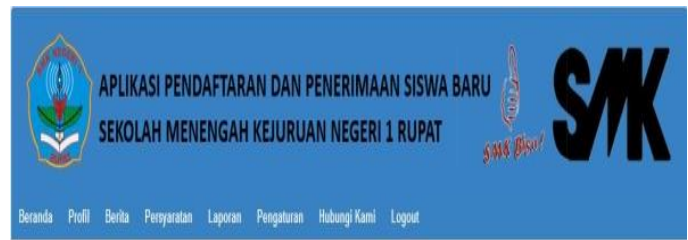

8. Laporan Data Pertahun Ajaran

Laporan data pendaftaran pertahun ajaran merupakan laporan data-data pendaftaran dan penerimaan calon siswa setiap tahunnya. Admin bisa mengecek data-data calon siswa baru setiap tahun sekali setelah siswa mendaftar.
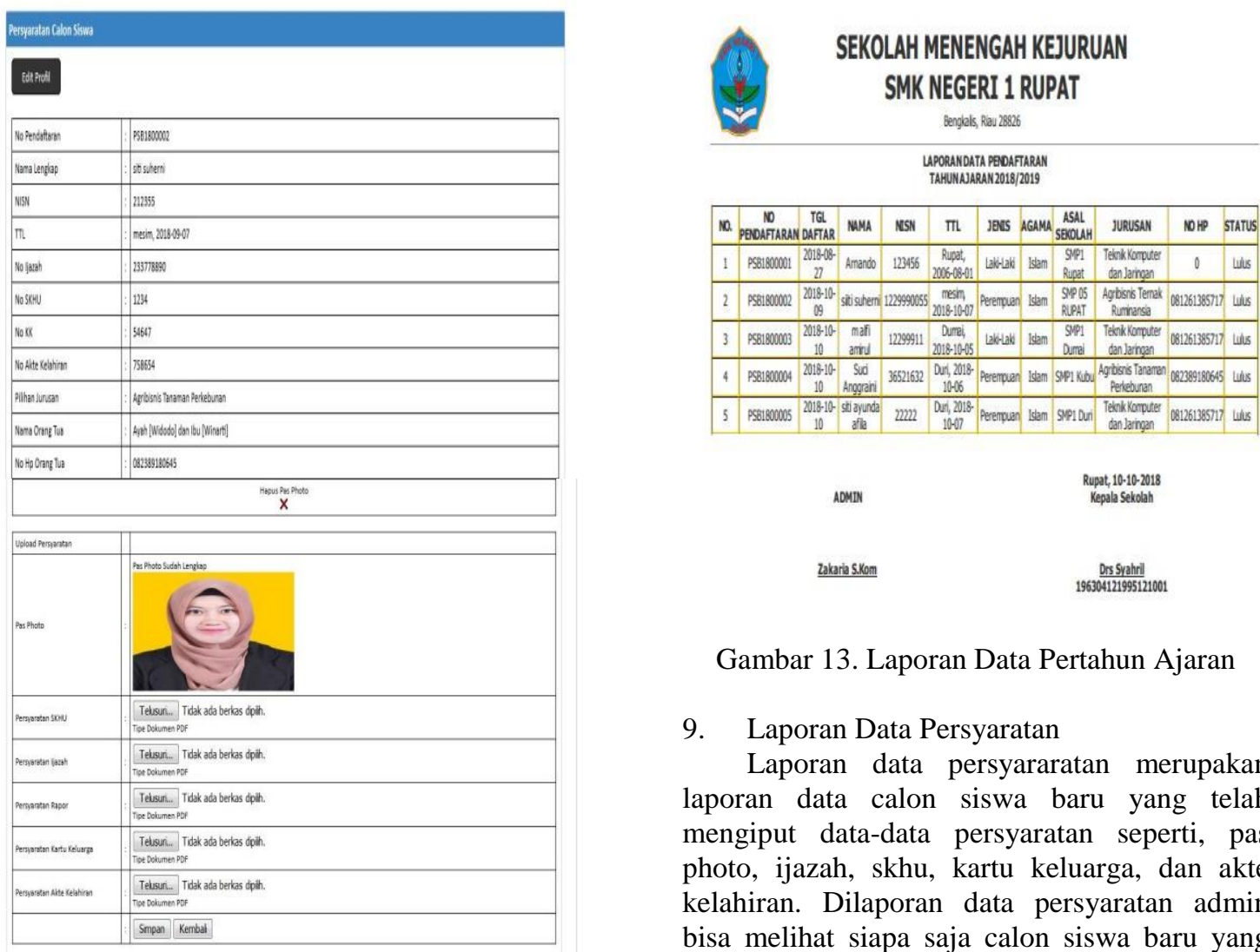

Gambar 13. Laporan Data Pertahun Ajaran

\section{Laporan Data Persyaratan}

Laporan data persyararatan merupakan laporan data calon siswa baru yang telah mengiput data-data persyaratan seperti, pas photo, ijazah, skhu, kartu keluarga, dan akte kelahiran. Dilaporan data persyaratan admin bisa melihat siapa saja calon siswa baru yang belum lengkap mengupload data persyaratan tersebut.

\section{Laporan Data Keseluruhan}

Laporan data pendaftaran keseluruhan merupakan laporan data-data calon siswa baru yang pertama mendaftar kesekolah SMK Negeri 1 Rupat sebelum melakukan data persyaratan tersebut.

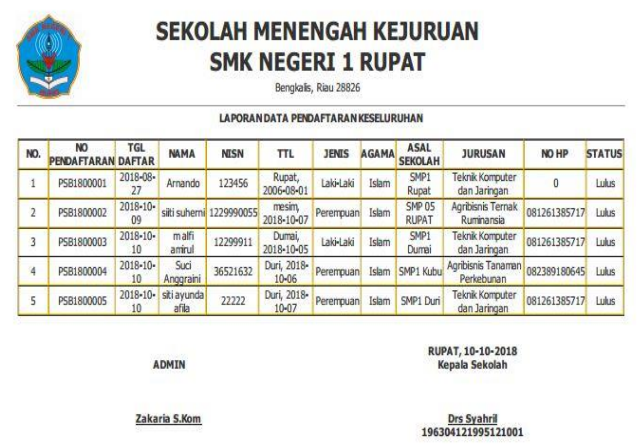

Gambar 12. Laporan Data Keseluruhan

Gambar 14. Laporan Data Persyaratan 
IN F ORM T IK A

Jurnal Informatika, Manajemen dan Komputer, Vol. 9 No. 2, Desember 2017

eISSN : 2580-3042

pISSN : 1979-0694

10. Laporan Data Siswa di Terima

Laporan data siswa di terima merupakan laporan data-data siswa yang mengikuti daftar ulang dan diterima masuk kesekolah SMK Negeri 1 Rupat.

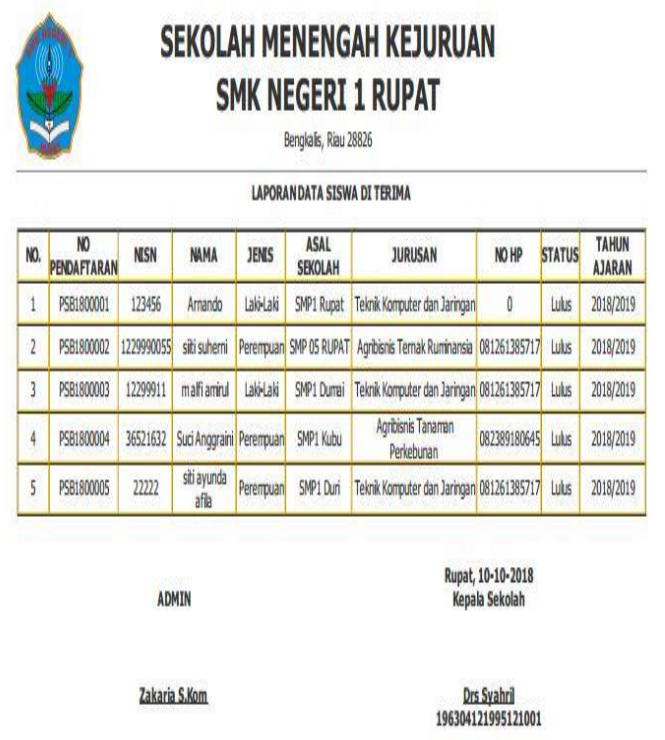

Gambar 15. Laporan Data Siswa di Terima

\section{KESIMPULAN}

Beberapa kesimpulan yang dapat diambil dari pembahasan dan penerapan Aplikasi Pendaftaran dan Penerimaan Siswa di SMK Negeri 1 Rupat Berbasis Web dan SMS Gateway.

1. Dengan di buatnya sistem ini dapat mempermudah pihak sekolah dalam pemberitahuan informasi pendaftaran dan penerimaan siswa baru kepeada orang tua/wali siswa.

2. Dengan adanya sistem ini siswa tidak perlu lagi datang kesekolah SMK Negeri 1 Rupat untuk mendaftarkan diri kesekolah tersebut karena sudah ada sistem online.

3. Dengan adanya sistem ini penyimpanan data akan lebih aman, didukung lagi dengan layanan pencarian data-data calon siswa baru yang dapat memberikan kemudahan dan kecepatan bagi pihak sekolah.

\section{REFERENSI}

Afrina, M., Ibrahim, A., Sistem, J., Fasilkom, I., \& Sriwijaya, U. (2015). Pengembangan Sistem Informasi Sms Gateway Dalam Meningkatkan Layanan Komunikasi Sekitar Akademika Fakultas Ilmu Komputer Unsri, 7(2), 852-864.

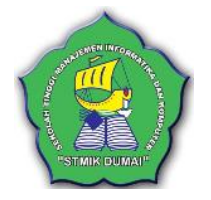

Bangun, R., Informasi, S., Sumbangan, P., Pendidikan, P., Insidental, D., Sekolah, P., ... Fristanto, T. (2014). Rancang Bangun Sistem Informasi Pembayaran Sumbangan Pembinaan Pendidikan (Spp) Dan Insidental Pada Sekolah Menengah Kejuruan Muhammadiyah Tinatar Punung Hendria Tony Fristanto, 3(4), 24-28.

Binarso, Y. A., Sarwoko, E. A., \& Bahtiar, N. (2012). Pembangunan Sistem Informasi Alumni Berbasis Web Pada Program Studi Teknik Informatika Universitas Diponegoro. Journal Of Information And Technology, 1(1), 72-84.

Dana Pranata, Hamdani, D. M. K. (2015). Rancang Bangun Website Jurnal Ilmiah Bidang Komputer (Studi Kasus : Program Studi Ilmu Komputer Universitas Mulawarman). Jurnal Informatika Mulawarman, 10(2), 25-29.

Iswandy, E. (2015). Sistem Penunjang Keputusan Untuk Menentukan Penerimaan Dana Santunan Sosial Anak Nagari Dan Penyalurannya Bagi Mahasiswa Dan Pelajar Kurang Mampu Di Kenagarian Barung - Barung Balantai Timur. Jurnal Teknoif, 3(2), 70-79. Https://Doi.Org/2338-2724

K, O. T., Irfan, M., Nurpianti, A., Teknik, J., \& Fakultas, I. (2013). Edisi Juli 2013 Volume Vii No. 1, Vii(1), 33-52.

Kaharu, S., Sakina, O., Informasi, S., \& Data, P. (2016). Perancangan Sistem Informasi Pengolahan Data Akademik Pada Tk AlHidayah Lolu, 2(1).

Palevi, A. R., \& Krisnawati. (2013). Analisis Dan Perancangan Sistem Informasi Penerimaan Peserta Didik Baru Berbasis Website Pada Smp Negeri 2 Mojosongo Boyolali. Jurnal Ilmiah Dasi, 14(04), 2-7.

Rubiati, N. (2018). Aplikasi Informasi Pelayanan Fitness Pada Golden Fitness Center Dumai Dengan Bahasa Pemrograman Php. Jurnal Informatika, Manajemen Dan Komputer, 10(1), 1-6. Retrieved From Http://Www.Ejournal.Stmikdumai.Ac.Id/I ndex.Php/Path/Article/View/53 
IN F ORM A I K A

Jurnal Informatika, Manajemen dan Komputer, Vol. 9 No. 2, Desember 2017

eISSN : 2580-3042

pISSN : 1979-0694

Saputra, R. (2015). Desain Sistem Informasi Order Photo Pada Creative Studio Photo

Dengan Menggunakan Bahasa Pemrograman Visual Basic.Net 2010. Jurnal Momentum, 17(1), 86-93. Retrieved From Gut_Ansehen_02@Yahoo.Com\%0aabstra $\mathrm{k}$

Sentosa, Y., Hadiansa, A., \& Rubiati, N. (2017). Aplikasi Pembuatan Kartu Pengenal Siswa Dan Siswi Sekolah Menengah Pertama (Smp) Ykpp Dumai. Jurnal Informatika, Manajemen Dan Komputer, 9(1), 44-48. Retrieved From Http://Www.Ejournal.Stmikdumai.Ac.Id/I ndex.Php/Path/Article/View/63

Witanto, R., \& Solihin, H. H. (2016). Perancangan Sistem Informasi Penerimaan Siswa Baru Berbasis Web ( Studi Kasus: Smp Plus Babussalam Bandung ). Infrotonik, 1(1), 54-63. Https://Doi.Org/Https://Doi.Org/10.1234/ Jtik.V6i2.107 